\title{
CAUSATIVE ALLIANCE BETWEEN MONETARY POLICY, INFLATION AND INFLATION RATE AT ECONOMIC SYSTEM IN PAKISTAN
}

\author{
Muhammad Ibrar \\ Department of Management Sciences, \\ International Islamic University Islamabad, Pakistan \\ E-mail address: msibrariiui@gmail.com
}

Keywords: monetary policy; inflation; interest rate; unemployment rate

\begin{abstract}
Purpose: This study examine both the monetary policy and inflation are the issues of high interest and importance, and how thus the studying them and their impact on the extension of the macroeconomic variables is a which are concerned for our culture/society.

The purpose of this proposal is focusing to identifying the existing connections between the inflation rate and some important macroeconomic indicators /variables and also on the dynamics of inflation at a national level. The main objective of this study is to reveal the causal relation between the inflation rate and the interest rate of the monetary policy and also between the inflation rate and the unemployment rate,

Conclusion: There is an inverse statistically significant relation between the inflation rate and the unemployment rate. This indicates that the inflation rate is an effective instrument in preventing the increase of in unemployment. Monetary policy has demonstrated,
\end{abstract}

\section{INTRODUCTION}

As the economic system monetary and inflation areas are the most significant factors. Which has always been uncertain? The currency may be considered a measure of recording, promptly and with great accuracy, the oscillations of a country's economy. Also, the main issues are mainly expressed in monetary terms.

Economic growth, GDP or the budgetary deficit cannot be analyzed without considering governmental policies (Monetary and budgetary) and their implications in promoting economic reforms. The monetary policy is a component of economic policy and can be defined as a set of actions, such as adjusting the quantity and cost of money, control of credited and money supply undertaken by the monetary authority of a country in order to influence the evolution of the national economy and to keep price stability. It represents an instrument of macroeconomic policy, which attempts to regulate the money supply, credit volume and interest rate in order to provide a good orientation for the economy.

Our analysis has focused on the dynamics of inflation in Pakistan and other Asian countries. Most of the current research that approach monetary issues has an econometric character. Both theory, as well as empirical studies indicate that the monetary policy may influence for a significant period of time not only prices, but also the employment rate, the GDP, the investments, economic growth and other important aspects of non financial economic activities.

Econometrics has an essential role in this area, because it represents an approach between theory and facts, thus the econometric analysis allows testing the hypothesis, verifying mathematical functions based on a variety of theories and building models to reflect reality.

The assertion that Pakistan, being a developing country, needs a high inflation rate (6 per cent or so) to support a 6-8 per cent GDP growth is seriously questionable and is not supported by hard evidence from the most recent comparable GDP growth and inflation data of some major emerging markets .

When most of major developing countries are recording healthy GDP growth while keeping overall inflation (this includes food and energy inflation) under five per cent, should not the government set five per cent inflation rate as target for the next fiscal year? This assumes additional 
significance - aside from domestic economy and political considerations in an election year - since the relatively higher inflation is hurting competitiveness and exports growth instead of supporting the declared policy objective of encouraging economic growth.

Macroeconomic analyses enforce a view of the economic field as a whole, including its emergent or recession periods, with at a level of production and services of the market, without neglecting price levels and their cyclic. Of employment levels that ensure ascertain level for production. The final objective of it all is to provide, in the long run, economic growth.

\section{LITERATURE REVIEW}

Keynesians claimed that the monetary policy may influence the aggregate demand, by modifying the money supply, which may lead to full employment, without generating inflation. Later, at the beginning of the ' 80 s, the Keynesian theories lose credibility and to the monetary ones, held high by economists such as Milton Friedman, Karl Brunner and Alton Meltzer, who suggest that monetary regulation can stabilize economy. The neoclassic economy brings in the rational expectations theory (Cerna, 2012,p.59).

In Gherman and Adam's study, the monetary policy aims at guaranteeing a high employment rate, as well as price stability. This double purpose, which is known and reviewed through literature as dual mandate of the monetary policy, may oppose the declared purpose of many central banks, which aim primarily, and sometime exclusively, at price stability(Gherman,2010, p.90). Gherman also considers that today few economists and businessmen, marketing vestors or otherwise, concerned about the evolution of the economy and the business opportunities, still believe that the actions of central banks have no impact on the evolution of the GDP and other important economic variables that have been in the public's attention.

The fact that monetary policies do not ensure a natural growth in employment or do not reach its correspondent GDP cannot be an excuse for lack of effort in sustaining these variables on an optimal level during business disturbances. Ina situation of dependency between global finances and high uncertainty, the ideal monetary policy should be highly comprehensive, it should be consistent, dynamic, transparent and responsible and it should avoid excessive fluctuation and flexibility (Solans, 2002). The reduced inflation of the last years is the result of a mixture of economic policies, favorable to disinflation, followed by restrictive monetary and fiscal policies

and an almost neutral budgetary policy. The monetary policy was mainly characterized by high interest rate and mandatory reserves and currency appreciation (Pop,2011). The economic literature highlights that, the contemporary economies, reaching a low and steady inflation creates a new economic climate, which requires a stringent reconsideration of the price stability and financial stability dependency.

\section{Price stability:}

The situation whereby the prices of goods and services offered in the marketplace either change very slowly or do not change at all. Factors affecting this include employment and inflation.

\section{Monetarypolicy:}

Economic strategy chosen by a government in deciding expansion or contraction in the country's money-supply. Applied usually through the central bank, a monetary policy employs three major tools:

(1) Buying or selling national debt, (2) changing credit restrictions, and (3) changing the interest rates by changing reserve requirements.

(2) Monetary policy plays the dominant role in control of the aggregate-demand and, by extension. 


\section{PRICESTABILITY- THE MAIN OBJECTIVE OF A MONETARY POLICY}

Price stability emerges as one of the most important objectives of the monetary policy. In pursuing the achievement of this objective there must be taken into consideration that the notion itself does not involve that all prices are stable or fixed. Pragmatically, the focus is on maintaining a steady mid-level, are relative stability and not an absolute one.

The definitions of price stability vary through literature some authors consider inflation expectances, while others use quantity terms to explain it. The American economist Alan Blinder (2009) stated: price stability is established when peoples top debating and worrying about inflation. Castelnuovo et.al.(2003,p.12)notice that the countries that practice inflation are getting regime do not use and explanatory definition of price stability, but this is characterized by the announcement of the inflation target. That price stability is the environment where economic agents, both people and companies, may decide regarding consumption and investments without considering inflation as a decisive influence (2003,p9).

Greenspan) defines price stability as the situation in which the influence of marking price levels is low enough not to make a difference for companies and household decisions.

Bernanke (2006), when referring to price stability, declares that it is both a purpose in itself, as well as a mean for monetary policy, because it contributes to economic growth and to macro Economic stability. We can consider that Price stability has been accomplished when currency can conserve its value through time or the erosion rate for the purchasing power is very low. In the paper "The monetary process: Essentials of money and banking", Marshall R. and Swanson R. (2009)

Emphasized that price stability represents an important objective for monetary policy because price instability, manifested as inflation, can have long and intense consequences on a national economy. The unfavorable side, starting from increased inflation, resides in the reduction of economic efficiency, in an unfair and whimsical distortion regarding the income distribution and in a downgrade of the international balance of payments.

The Central European Bank considers price stability to be a yearly increase smaller than 2\% of the harmonized index of consumer prices (HICP) for the euro zone. A similar definition was given by the Swiss National Bank prices ability represents an increase smaller than $2 \%$ of the index of consumer prices.

Fischer (2008) considers that, operationally speaking, price stability should represent an inflation rate between and 3\%. In the paper "The Role of Macroeconomic Factors in Growth" he states that macroeconomic stability, including inflation control, is a must for economic growth.

Meltzer (2009) combines quantitative and qualitative aspects, stating that price stability implies an inflation rate so close to as it becomes an important factor in long-term planning, considering that a 3\% inflation is too high for this objective. The high rate of inflation of the past century required a deep reform process, during which central banks were held responsible for reaching target points of inflation. In Romania, at the beginning of the last century, the goal was to sustain monetary stability while no price increase. Startingwiththe1960's, an annual increase in prices is settled to be between $3 \%$ and $4 \%$.

One of the most significant developments in the current economic scene in Pakistan has been the sharp increase in the rate of inflation. The annual average rate of increase in the wholesale price index (WPI) during the first seven months (July-January 1994-95) of the current fiscal year has been about 19 percent as opposed to 11.3 percent during the same period last year. A similar increase was also witnessed in the consumer price index (CPI) which accelerated to 13 percent as opposed to 11.1 percent during the previous period. Such a sharp increase in prices in recent months has not only caused alarm in the academic circles but has equally disturbed the country's chief executive, the Prime Minister. The recent surge of inflation is a matter of serious concern for a variety of reasons. First, Pakistan has been a low-inflation country as it has experienced price stability during the last three decades. The rate of inflation, as measured by an increase in the WPI, averaged 2.6 percent during the 1960s. The components of the WPI, i.e., food, raw materials, manufactures, and fuel and lubricants, also grew by an average rate ranging from 2.0 to 3.4 percent 
p.a. during then 1960s (see Table 1 for relevant statistics). The rate of inflation crossed the singledigit threshold during the 1970s. The WPI and its components increased at an annual average rate ranging from 12 to 18 percent. The double-digit inflation during the 1970s has been the result of two major oil shocks, a massive devaluation of currency, and devastating floods destroying agricultural crops. Pakistan returned to the fold of the single-digit inflation during the 1980s. The rate of inflation remained at the single-digit level during the first three years of the 1990s with the exception of 1990-91, when the rate of inflation increased to 11.7 percent as a result of the Gulf War. It is only during the outgoing fiscal year and in the current year that the rising inflation is posing a major threat to macroeconomic stability.

Pakistan's economy over the years showed fairly good economic growth with a modicum of price stability, despite the fact that it has gone through a massive devaluation, oil Rapid increase in the oil prices, wheat shortage, increase in money supply, growth rate in credit availability to private sector are the highlighted shocks, crop failures, floods, Afghan war, earthquake, rapid political changes, military authoritarianism, war on terror and inconsistency of economic and development policies. It surprised observers by surviving in the worst economic crises but failed to deliver in times of macro stability. The economy has seen GDP growth rate of 6 per cent or more. It is obvious that GDP growth has been inflationary in Pakistan and inflation lies low in terms of priorities. Inflation became a matter of concern only since around the start of the 1990s, coinciding with the start of structural adjustment programme with the IMF. 4.1 Historical account of inflation in Pakistan Pakistan's inflation rate over the years has been satisfactory according to most analysts.

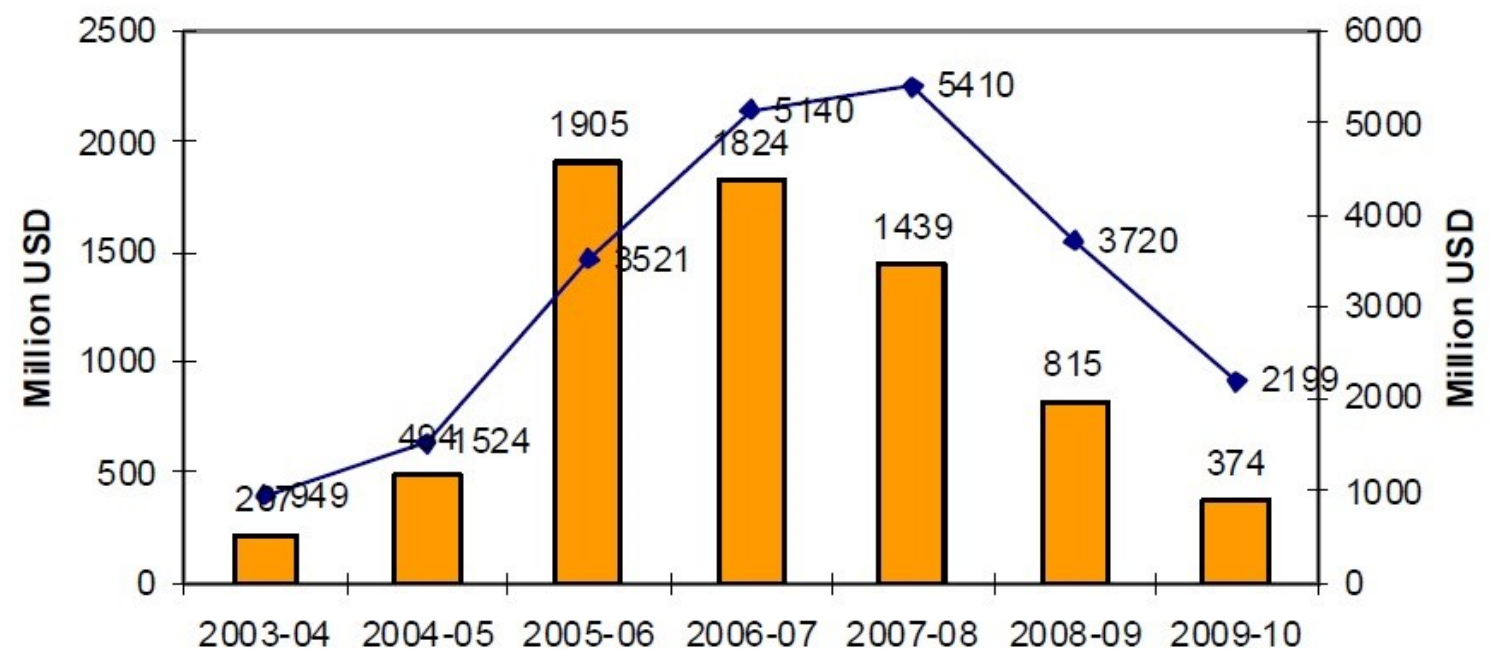

$\square$ FDI in Telecom $\longrightarrow$ Total FDI

\section{EMPIRICAL STUDY}

There has been a lot of talk regarding the right level of monetary policy's interest rate. Some analysts consider that the interest rates should have been drastically reduced when production crashed, in order to mitigate the effects of the crisis. Lowering monetary policies interest rate in Romania was justified by significantly reducing the inflation rate. The RNB practiced a policy of interest rate which aimed to ensure both minimizing targeted inflation deviation,As well as potential production, in order to provide inflation stability. It has to be mentioned that, after going into recession in 2008 ,

The central bank cannot influence price directly, but it can control it by managing interest rate. This may serve both as an acceleration instrument for the economy and a means for braking it.

Our objective is to demonstrate the causal relationship between inflation and monetary policy interest rate and the causal relationship between unemployment and inflation. For this purpose we use a simple linear regression model. 


\section{HYPOTHESIS}

Hypothesis about the causal relationship between inflation rate and interest rate

H1: We assume that there is a causal relation between the independent variable of monetary policy interest rate and the dependent variable of inflation rate, between them being a direct connection. Hypothesis regarding the causal relationship between inflation and unemployment

H2: We assume that there is a causal relation between the independent variable of inflation rate and the dependent variable of the unemployment rate, between them being an indirect connection.

\section{CONCLUSIONS}

Our empirical results emphasize a significant direct relation between that monetary policy interest rate and inflation, which make interest rate an efficient instrument for central bank to prevent inflation. Because Pakistan inflation is susceptible to unexpected changes in the interest rate, a good alternative for companies would be to make decisions based on interest rate evolution forecast. We can also state that protecting interest rate is a lever for inflation targeting

Strategies Also, there is an inverse statistically significant relation between the inflation rate and the unemployment rate. This indicates that the inflation rate is an effective instrument in preventing the increase of in unemployment. Monetarypolicy has demonstrated, throughout history, that its main role is to reduce inflation and to achieve price control. If this objective is accomplished, the economy gains a necessary credibility climate for healthy, efficient and durable economic growth. Monetary policy is committed to expand on the mains structural variables and causal relations involved in guaranteeing a state of equilibrium, by offering to the monetary theory and practice the possibility of choosing and logically connecting macroeconomic variables. For many analysts and businessmen, monetary policy still owes a solution to recession. In a global framework of financial interdependence and increased uncertainty, the monetary policy should ideally be characterized by commitment, consistency, dynamics, transparency, accountability, quality assessment and avoidance of excessive fluctuation and flexibility; set of attributes that inevitably involve a high degree of complexity.

\section{References}

[1] Applied Economics, Volume XVII(2010), No.12(553), pp. 89 - 94;

[2] Greenspan, A., (1996), Opening Remarks, on the Federal Reserve Bank of Symposium Achieving Price Stability;

[3] Necsulescu, C.,Serbanescu, L.,(2013), Impact of the inflation on the exchange rate and on the average salary, Cross - Cultural Management Journal, VolumeXV,Issue 3(29), 2013, pp222227 ;

[4] Oroianu, M.,Radnoti-Szakacs, A.,Simfoni,A.,(2013), An empirical study on causal relation between inflation rate one macroeconomics variables, Academia Science Journal Studia Series, No(2)1, 2013;

[5] Pop, N. (2011), Monetary policy decision -the fascinating theory and the ineffable institution, Expert Publishing House, Bucharest; Necsulescu, C., Serbanescu, L., Impact of the inflation on the exchange rate and on the average salary, Cross-Cultural Management Journal,VolumeXV, Issue 3(29), 2013, pp222-227;

[6] Tanascovici, M.,BranzeaV.M.,(2010), Inflationtargeting and theleu exchange rateandtheinterest rates implications on economic activity, Annals Economics Science Series. Timisoara,Volume XVI (2010), pp.505-509; 